\title{
Co mi provedl Jiří Gabriel, muž všetečných otázek
}

\section{What Jiří Gabriel - A Man of Tricky Questions - Did to Me}

\author{
Josef Krob
}

Je toho hodně a na všechno si určitě nedokážu vzpomenout. Tak třeba seděl ve zkušební komisi u přijímacích zkoušek na fakultu, obor filosofie a kladl mi záludné otázky, jako třeba byla ta, zda vím, jaký je rozdíl mezi tvrzením „Existuje Bůh“ a „Věřím, že existuje Bůh“. Dnes by pravděpodobně uchazeče otázka nevyvedla z míry tak jako mě v roce 1976, kdy jsem za tím hledal bůhvíjaký ideologický chyták. Nějak jsem se z toho vymotal, byl přijat a stal se jedním z mnoha, ke kterým mírily další otázky. Jiří Gabriel seděl v Akádě a nabourával naši studentskou filosofickou suverenitu tichým nasloucháním našim moudrým začátečnickým debatám a čas od času nás vykolejil - ke kolejím a vlakům on měl totiž velmi blízko - nějakou nevinnou otázkou. Jiří Gabriel seděl také u některých zkoušek - z dějin české a slovenské filosofie, z vybraných otázek teorie kultury, z vědeckého ateismu - ale zde se paradoxně ptal velmi málo, nechával nás říkat, co víme. $O$ to více se pak ale ptal na oslavách, které následovaly po zkouškách: „Kdo je podle vás nejvýznamnější filosof v celých dějinách? A proč?", nenechal nás marnit čas prázdným oslavováním. Nějak jsem se z toho vymotal, absolvoval jsem a nastoupil na katedru jako asistent. Otázka „Zúčastníš se konference, kterou právě pořádáme?“ patřila do kategorie těch, na něž byla možná jen kladná odpověd', volitelné bylo jen zpřesnění tématu příspěvku, který jsem měl vypracovat. Ale gabrielovské konference a publikace jsem popsal již před deseti lety ${ }^{1}$ a na tom se nic nezměnilo.

1 KROB, Josef. Jiří Gabriel je Jiří Gabriel. Studia philosophica. 2010, 57(1) s. [9]-14. On-line http://hdl.handle.net/11222.digilib/115501. 
Otázky Jiřího Gabriela se samozřejmě netýkaly jen filosofie. Kromě nádraží a vlaků jej zajímalo mnoho dalšího a svých dotazů se nevzdal ani po pohřbu Jiř́ího Cetla, kdy v hospodě zjištoval, zda všichni víme, že sex po pohřbu bývá velmi intenzivní a jak se s tím vypořádáme. Jiří Gabriel se ptal i na čistě praktické a technické věci. Když se v mé pracovně objevilo nové zařízení, scanner dokumentů, intenzivně se zajímal o to, jak funguje. Zneužil jsem situace, přibližně jsem ho seznámil s principem a vyzval jej, at se na to podívá sám hezky zblízka. A tak Jiř́i Gabriel strčil hlavu do scanneru a dostal odpověd':

A co mi tedy provedl Jiří Gabriel? Vůbec nic špatného. Ujistil mne $\mathrm{v}$ přesvědčení, že klást otázky je dobré a užitečné, a to třeba i za cenu, že u toho nevypadáte zrovna reprezentativně. Děkuji.

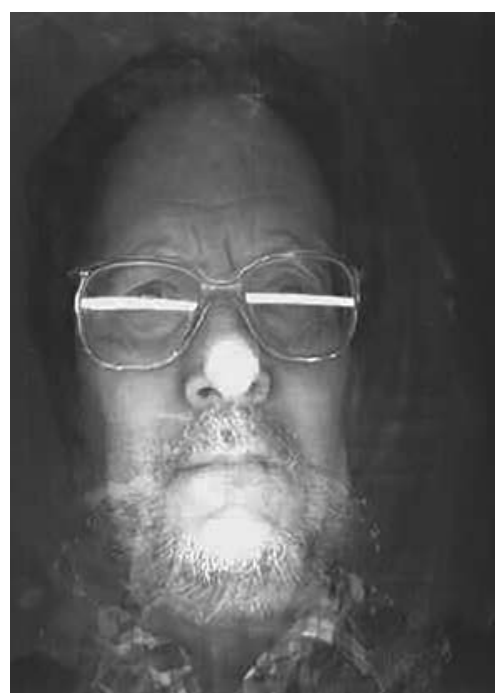

prof. PhDr. Josef Krob, CSc.

Katedra filozofie, Filozofická fakulta, Masarykova univerzita

Arna Nováka 1, 60200 Brno, Česká republika

jokr@phil.muni.cz

Toto dílo Ize užít v souladu s licenčními podmínkami Creative Commons BY-NC-ND 4.0 International (https://creativecommons.org/licenses/by-nc-nd/4.0/legalcode). Uvedené se nevztahuje na díla či prvky (např. obrazovou či fotografickou dokumentaci), které jsou v díle užity na základě smluvní licence nebo výjimky či omezení př́slušných práv. 